\title{
Endocrine changes during pregnancy, parturition and the early post-partum period in the llama (Lama glama)*
}

\author{
J. B. Leon $\dagger$, B. B. Smith $\ddagger$, K. I. Timm $\ddagger$ and G. LeCren $\ddagger$ \\ $\dagger$ Department of Animal Science College of Agriculture, and $\ddagger$ College of Veterinary Medicine, \\ Oregon State University, Corvallis, Oregon 97331, USA
}

\begin{abstract}
Summary. Mean ( \pm s.d.) pregnancy length for the 14 llamas in this study was $350 \pm 4 \cdot 5$ days. Plasma progesterone concentrations increased by 5 days after mating and remained elevated $(>2.0 \mathrm{ng} / \mathrm{ml})$ throughout most of pregnancy. At about 2 weeks before parturition, plasma progesterone concentrations began to decline, dropped markedly during the final $24 \mathrm{~h}$ before parturition, and returned to basal concentrations $(<0.5 \mathrm{ng} / \mathrm{ml})$ by the day of parturition. The combined oestrone + oestradiol- $17 \beta$ and oestradiol-17 $\beta$ concentrations varied between 6 and $274 \mathrm{pg} / \mathrm{ml}$ and 4 and $114 \mathrm{pg} / \mathrm{ml}$, respectively, during the first 9 months of pregnancy. Concentrations increased between 9 months after mating and the end of pregnancy with peak mean concentrations of $827 \pm 58$ (s.e.m.) pg oestrone + oestradiol-17ß/ml (range: 64-1658) and $196 \pm 10 \mathrm{pg}$ oestradiol $-17 \beta / \mathrm{ml}(31-294)$ during the last week of pregnancy. Concentrations then declined to $87 \pm 14 \mathrm{pg}$ oestrone + oestradiol $-17 \beta / \mathrm{ml}(7-488)$ and $25 \pm 5 \mathrm{pg}$ oestradiol$17 \beta / \mathrm{ml}(2 \cdot 5-142)$ during the first week post partum. Plasma cortisol concentrations varied between 2.6 and $51.9 \mathrm{ng} / \mathrm{ml}(14.0 \pm 0.5)$ from mating until 2 weeks before parturition when the concentrations began to decline. Only a slight increase in plasma cortisol concentrations was observed in association with parturition. Plasma triiodothyronine concentrations varied between 0.5 and $4.5 \mathrm{ng} / \mathrm{ml}(1.9 \pm 0.1)$ throughout pregnancy and the periparturient period. Plasma thyroxine concentrations varied between 21.3 and $91.5 \mathrm{ng} / \mathrm{ml}(56.5 \pm 0.8)$ from mating until about 39 weeks of pregnancy when they began to decline, from $43.0 \pm 5 \cdot 3 \mathrm{ng} / \mathrm{ml}$ at 15 days pre partum to $23.5 \pm 5.5 \mathrm{ng} / \mathrm{ml}$ immediately before parturition, but then increased to $52.8 \pm 3.9 \mathrm{ng} / \mathrm{ml}$ by 1 day post partum.
\end{abstract}

Keywords: llama; pregnancy; post partum; progesterone; oestrogen; parturition

\section{Introduction}

The hormonal changes associated with pregnancy, parturition and the post-partum period in the llama (Lama glama) are poorly defined. A detailed understanding of the normal hormonal changes observed during these periods will allow better management, treatment, or prevention of fertility problems in this species.

The endocrine changes occurring during pregnancy, parturition, and the early post-partum period have been studied in numerous species (Wagner et al., 1974; Bazer \& First, 1983). A decline in serum progesterone concentration before parturition occurs in the cow (Fairclough et al., 1975a; Hunter et al., 1977), ewe (Chamley et al., 1973; Thompson \& Wagner, 1974), pig (Molokwu \& Wagner, 1973; Robertson \& King, 1974), goat (Thorburn et al., 1972), and dromedary camel, a

\footnotetext{
*Reprint requests to: Dr B. B. Smith, College of Veterinary Medicine, Oregon State University, Corvallis, Oregon 97331-4802, USA
} 
species phylogenetically related to the llama (Elias et al., 1984b). In contrast, progesterone concentrations in women and other primates decline during or shortly after parturition (Llauro et al., 1968; Csapo et al., 1971). A rise in glucocorticoid concentrations preceding parturition has been reported in the cow (Adams \& Wagner, 1970; Smith et al., 1973), ewe (Thompson, 1973; Thompson \& Wagner, 1974), and pig (Ash \& Heap, 1975; First \& Bosc, 1979). Total serum oestrogen and oestradiol-17 $\beta$ concentrations have been observed to increase in several species before parturition (Bedford et al., 1972), including the cow (Stabenfeldt et al., 1970; Peterson et al., 1975; Hoffman et al., 1977), ewe (Bedford et al., 1972; Thompson, 1973), and pig (Wagner \& Oxenrider, 1971; Guthrie et al., 1972; Molokwu \& Wagner, 1973). Elias et al. (1984b) and Agarwal et al. (1987) reported a similar increase in oestrogen concentrations in the camel 2 days before parturition. Soliman et al. (1963) suggested that thyroid hormones increased during late pregnancy in the cow, while Heshmat et al. (1984) reported that plasma triiodothyronine and thyroxine concentrations in the dromedary camel increased throughout pregnancy.

The purpose of this study was to characterize the changes in plasma progesterone, triiodothyronine, thyroxine and cortisol, and serum oestradiol-17 $\beta$ and total oestrogen concentrations during pregnancy, parturition and the early post-partum period in the llama.

\section{Materials and Methods}

Animals. Fourteen 4-8-year-old, multiparous, healthy, female (136-150 kg body weight) and 3 intact male (5-12 years of age) llamas from a commercial herd in the Willamette Valley of Oregon were used in the study. Animals were fed a combination of grass hay and allowed free access to pasture. Trace-mineral salt mix and water were available ad libitum. Following breeding practices used by the farm operator, the animals were mated twice at 6-h intervals to 1 of the 3 males. The males were separated from the females for the remainder of the study. The day of mating was designated Day 0 .

Blood sampling. Blood samples were collected from mid-July 1987 to August 1988. Samples were collected every other day for the first 30 days after mating and then at 7-day intervals between 30 and 60 days of pregnancy. Starting 60 days after mating, samples were collected at monthly intervals until the end of the 10th month of pregnancy; one sample was collected at 10.5 months, and then 3 times per week until 1 week post partum. Animals that failed to conceive as determined by serum progesterone determinations and the birth of a live offspring were not included in the study. Blood was collected into evacuated serum and EDTA tubes (Becton-Dickinson, Rutherford, NJ, USA) by puncture of the internal jugular vein. The EDTA samples were placed on ice and centrifuged within $2 \mathrm{~h}$ of collection. Plasma was stored at $-20^{\circ} \mathrm{C}$ until analysed. Serum samples were allowed to clot at room temperature for $30 \mathrm{~min}$, centrifuged, and the serum stored at $-20^{\circ} \mathrm{C}$ until analysed.

Progesterone assay. The direct-reading solid-phase assay (Diagnostic Products Corporation, Los Angeles, CA, USA) was validated for use in the llama by evaluating recoveries foliowing the addition of known amounts of progesterone to llama samples. After addition of $0 \cdot 5,2 \cdot 0$ and $10.0 \mathrm{ng}$ progesterone to a llama plasma pool containing $<0.5 \mathrm{ng}$ progesterone $/ \mathrm{ml}$, mean recoveries were $92 \cdot 0 \% \pm 2.0 \%, 99 \cdot 0 \% \pm 14.0 \%$ and $105.0 \% \pm 7.0 \%$, respectively. After addition of 50,100 and $200 \mu$ llama plasma pooled from 3 samples, progesterone concentrations of $1 \cdot 3 \pm 0 \cdot 2$, $2 \cdot 1 \pm 0 \cdot 1,3 \cdot 9 \pm 1 \cdot 6 \mathrm{ng} / \mathrm{ml}$, respectively, were measured. All assays were conducted using a sample volume of $100 \mu \mathrm{l}$ plasma using incubation times and protocols outlined by the manufacturer. Parallelism between the log-logit plotted standard curve and the variable added volumes of llama plasma was evaluated by comparison of regression slopes using a Student's $t$ test. The slopes did not differ $(P>0.05)$. Reported antibody cross-reactivity was $100 \%$ with progesterone, $2.0 \%$ with $20 \alpha$-dihydroprogesterone, $1.7 \%$ with 11 -deoxycorticosterone, $2 \cdot 4 \%$ with 11 -deoxycortisol, and $1.3 \%$ with $5 \beta$-pregnan-3,20-dione. All other tested steroids had $<1.0 \%$ cross-reactivity. Samples were run in a total of 17 assays with intra- and interassay coefficients of variation of $6 \%$ and $16 \%$, respectively. The assay sensitivity was $0.1 \mathrm{ng} / \mathrm{ml}$ and represented approximately $91 \%$ binding relative to the $\mathrm{B}_{0}$ tubes.

Cortisol assay. The solid-phase commercial assay (Diagnostic Products Corporation) was validated for use in the llama by evaluating recoveries following the addition of cortisol to llama plasma samples. After addition of $4 \cdot 0,8 \cdot 0$ and $40.0 \mathrm{ng}$ cortisol $\mathrm{ml}$ to llama plasma containing $<5 \mathrm{ng}$ cortisol $/ \mathrm{ml}$, mean recoveries were $99 \cdot 0 \% \pm 1 \cdot 0,104 \cdot 0 \% \pm$ 0.6 and $90.0 \% \pm 2 \cdot 0$, respectively. After addition of 25,50 and $100 \mu$ l llama plasma pooled from 3 samples, cortisol concentrations of $26 \cdot 0 \pm 3 \cdot 0,48 \cdot 0 \pm 4 \cdot 0$, and $94 \cdot 0 \pm 2 \cdot 0 \mathrm{ng} / \mathrm{ml}$, respectively, were measured. All assays were conducted using a sample volume of $50 \mu \mathrm{l}$. Parallelism between the log-logit plotted standard curve and the variable added volumes of llama piasma was evaluated as previously outlined. The slopes of the regression lines did not differ $(P<0.05)$. Reported antibody cross-reactivity was $100 \%$ with cortisol, $1.4 \%$ with corticosterone, $0.25 \%$ with deoxycortisol and $1 \cdot 5 \%$ with 11-deoxycorticosterone. All other tested endogenous steroids had $<0 \cdot 1 \%$ cross-reactivity. The assay was run under conditions specified by the manufacturer. Samples were run in a total of 9 assays with an 
intra- and interassay coefficients of variation of $9 \%$ and $10 \%$, respectively. The assay sensitivity was $5 \mathrm{ng} / \mathrm{ml}$ and represented approximately $84 \%$ binding relative to the $\mathbf{B}_{0}$ tubes.

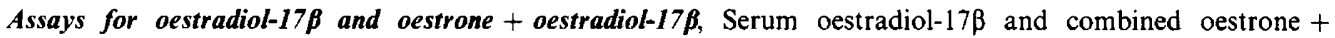
oestradiol-17 $7 \beta$ concentrations were measured using commercial radioimmunoassay kits (Radioassay Systems Laboratories, Carson, CA, USA) validated for use in the llama. Before measurement by RIA, samples were extracted by mixing $800 \mu \mathrm{l}$ serum with $8 \mathrm{ml}$ of a ethyl acetate:hexane $(3: 2, \mathrm{v}: \mathrm{v})$ mixture. The mixture was vortex-mixed, and the organic phase containing the conjugated oestrogens removed by aspiration. The aqueous phase was dried under nitrogen at $40^{\circ} \mathrm{C}$, and reconstituted with $2.4 \mathrm{ml}$ assay buffer $(0.1 \mathrm{M}$-phosphate-buffered saline with gelatin, $\mathrm{pH} 7.9)$ before overnight storage at $4^{\circ} \mathrm{C}$. Each assay tube contained $0.5 \mathrm{ml}$ of the diluted sample, $0.1 \mathrm{ml}{ }^{125} \mathrm{I}$-labelled oestrogen-17及 and $0.1 \mathrm{ml}$ of either anti-oestrone + oestradiol- $17 \beta$ or anti-oestradiol- $17 \beta$ antiserum (depending on the assay). After incubation for $90 \mathrm{~min}$ at room temperature, $400 \mu \mathrm{l}$ anti-rabbit-IgG in $3 \%$ polyethylene glycol were added and incubated for an additional $60 \mathrm{~min}$ at room temperature. The samples were centrifuged at $1500 \mathrm{~g}$ for $30 \mathrm{~min}$, the supernatant was decanted and the tubes dried and counted in a gamma counter equipped with automated data-reduction facilities (Cobra, Packard Instrument Corporation, Chicago, IL, USA). In initial studies, extraction efficiency was evaluated by adding trace amounts of $\left[{ }^{3} \mathrm{H}\right]$ oestradiol- $17 \beta$ to serum and measuring the activity following the extraction procedure. Due to the high and consistent recoveries $(91 \pm 3 \%)$, assay values were not corrected for extraction efficiency. Serum blank values were subtracted from assayed samples. The minimum detectable oestradiol- $17 \beta$ and oestrone + oestradiol$17 \beta$ concentrations for both assays were $2.5 \mathrm{pg} / \mathrm{ml}$ and represented approximately 80 and $88 \%$ binding, respectively, relative to the $B_{0}$ tubes.

Oestrone + oestradiol-17ß assay. The assay was validated for use in the llama by evaluating recoveries following the addition of known amounts of oestradiol-17 $\beta$ to llama samples. Following the addition of 50,100 and $200 \mathrm{pg}$ oestradiol $-17 / \mathrm{ml}$ to llama serum containing $83 \mathrm{pg}$ total oestrogen $/ \mathrm{ml}$ mean recoveries were $96 \cdot 0 \pm 10 \cdot 0 \%, 88 \cdot 2 \pm$ $19 \cdot 0 \%$ and $94.0 \pm 13.0 \%$, respectively. After addition of 250,500 and $1000 \mu 1$ serum pooled from 3 animals, total concentrations of $45 \pm 4,76 \pm 12$ and $139 \pm 12 \mathrm{pg} / \mathrm{ml}$, respectively, were measured. The slope of the regression lines fitted to the standard curve and the added volumes of llama serum did not differ $(\boldsymbol{P}>0.05)$. Reported antibody crossreactivity was $100 \%$ with oestradiol- $17 \beta, 9 \%$ with oestriol, $7 \%$ with oestradiol- $17 \alpha$, and $100 \%$ with oestrone. All other tested treated steroids had $<0.01 \%$ cross-reactivity. All assays were conducted using a sample volume of $800 \mu$ l. Samples for total oestrogen were run in a total of 10 assays with intra- and interassay coefficients of variation of $6 \%$ and $14 \%$, respectively.

Oestradiol-17ק assay. The assay was validated for use in the llama by evaluating recoveries after spiking of unknown llama samples. Following the addition of 50,100 and $200 \mathrm{pg}$ oestradiol $-17 \beta / \mathrm{ml}$ to pooled llama serum containing $24 \mathrm{pg}$ oestradiol- $17 \beta / \mathrm{ml}$, mean recoveries were $102 \cdot 0 \pm 14 \%, 96 \cdot 0 \pm 19 \%$ and $95 \cdot 0 \pm 9 \cdot 0 \%$, respectively. After addition of 250,500 and $1000 \mu 1$ of serum pooled from 3 animals, oestradiol-17 $\beta$ concentrations of $29 \pm 4$, $60 \pm 11$ and $113 \pm 11 \mathrm{pg} / \mathrm{ml}$, respectively, were measured. The slope of the regression lines fitted to the standard curve and the added volume of llama serum did not differ $(P>0.05)$. Reported antibody cross-reactivity was $100 \%$ with oestradiol- $17 \beta, 6.5 \%$ with oestriol, $5.2 \%$ with oestradiol- $17 \alpha, 0.55 \%$ with oestrone, and $0.38 \%$ with equilin. All other tested steroids had $<0.01 \%$ cross-reactivity. All assays were conducted using a sample volume of $800 \mu$ l. Samples were run in a total of 10 assays with intra- and interassay coefficients of variation of $5 \%$ and $16 \%$, respectively.

Triiodothyronine and thyroxine assays. The direct-reading solid-phase assays (Diagnostic Products Corporation, Los Angeles, CA, USA) have been previously validated for use in the llama (Smith et al., 1989). The sensitivities for the assays were $0.2 \mathrm{ng} / \mathrm{ml}$ triiodothyronine and $10 \mathrm{ng}$ thyroxine $/ \mathrm{ml}$. Binding at these concentrations represented approximately $83 \%$ binding relative to the $\mathrm{B}_{0}$ tubes for both assays. Samples were run in a total of 5 assays with intraand interassay coefficients of $4 \cdot 5 \%, 9 \cdot 1 \%$ and $6.0 \%, 8.9 \%$ for the triiodothyronine and thyroxine assays, respectively.

Statistical procedures. Hormone concentrations and variance are reported as the mean and the standard error of the mean (s.e.m.), respectively. Temporal changes in hormone concentrations during the last 2 weeks of pregnancy were evaluated by fitting a linear regression to the data. The null hypothesis that the regression slope was equal to 0 was tested using a Student's $t$ test. The data collected between Days 1 and 7 post partum were tested in the same manner. Analysis of the data was performed using the Statistical Applications System (SAS) program (version 6.0) running on a microcomputer.

\section{Results}

The 14 animals in the study had a pregnancy of $350 \pm 4.5$ days (standard deviation) (range: 346-359 days). All animals had normal unassisted deliveries.

Changes in plasma progesterone, serum oestradiol-17 $\beta$ and combined oestrone + oestradiol-17 $\beta$ concentrations during the first 35 days after conception are shown in Fig. 1. Mean progesterone, oestradiol-17 $\beta$, combined oestrone + oestradiol-17 $\beta$, triiodothyronine, thyroxine and cortisol concentrations from conception until 1 week post partum are shown in Fig. 2. To facilitate visualization of the data during periods of frequent sampling, data from samples collected within a 7-day period 
were pooled (mean $=18$; range: $5-37$ samples/datum point). Due to the variability in the length of pregnancy, the changes in hormone concentrations from individual animals were more pronounced than indicated in Fig. 2. To examine more clearly the endocrine changes associated with parturition, the day of parturition for each animal was defined as Day 0 . Hormone concentrations for the 15 days before parturition and the first 7 days post partum are shown in Fig. 3, plotted relative to the day of parturition. Each datum point represents a mean of 6 observations (range: 3-11 samples/datum point).

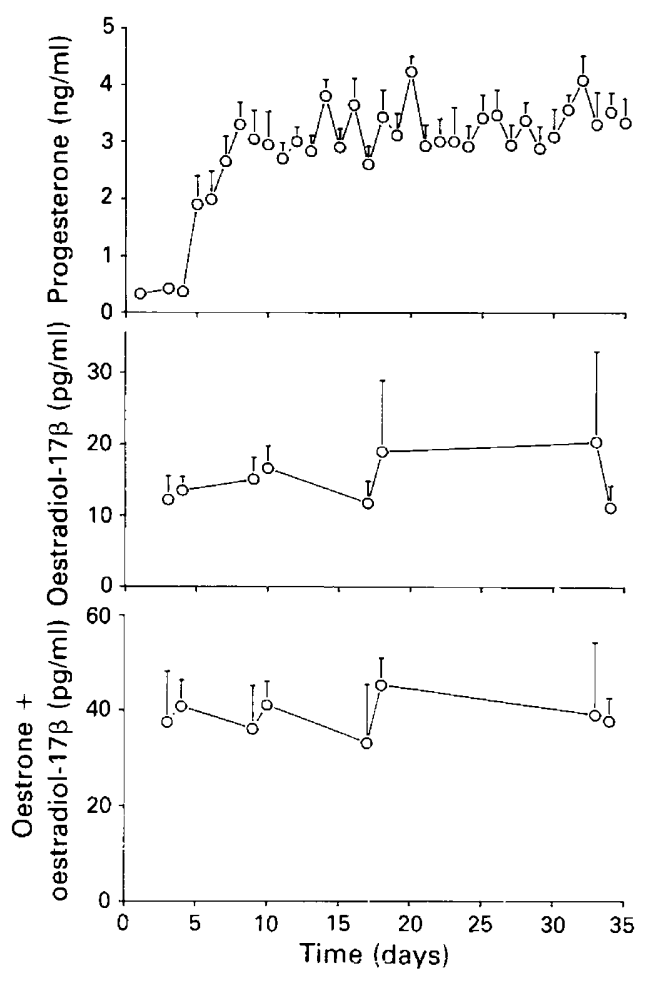

Fig. 1. Mean ( \pm s.e.m.) plasma progesterone, and serum oestradiol-17 $\beta$, and combined oestrone + oestradiol-17 $\beta$ concentrations from Day 0 (day of mating) to Day 35 of pregnancy in the llama $(\mathrm{N}=14)$.

Plasma progesterone concentrations increased by 5 days after mating (Fig. 1) and remained $>2.0 \mathrm{ng} / \mathrm{ml}$ until 15 days before parturition (Fig. 3). Between 15 and 1 days pre partum, progesterone concentrations declined significantly $(P<0.001)$ from a mean concentration of $3.8 \pm 0.8$ to $1.4 \pm$ $0 \cdot 2 \mathrm{ng} / \mathrm{ml}$. Between Day 1 pre partum and the day of parturition, progesterone concentrations further declined to $0.4 \pm 0.1 \mathrm{ng} / \mathrm{ml}$. During the first week post-partum progesterone concentrations remained low $(<0.5 \mathrm{ng} / \mathrm{ml})$ and did not change significantly $(P>0.05)$.

Plasma cortisol concentration remained relatively constant $(14.0 \pm 9.0 \mathrm{ng} / \mathrm{ml})$ through most of pregnancy. Cortisol concentration increased slightly $(26 \cdot 0 \pm 4 \cdot 1 \mathrm{ng} / \mathrm{ml})$ at Week 45 of pregnancy and then declined to earlier concentrations. Between 15 and 1 days pre partum, cortisol concentration decreased significantly $(P<0.01)$ from a mean concentration of $18.7 \pm 5 \cdot 1$ to $11.7 \pm 2.3 \mathrm{ng} / \mathrm{ml}$. There was a slight but non-significant increase in cortisol concentrations on the day of parturition. Cortisol concentration did not change significantly with time during the post-parturient period $(P>0 \cdot 05)$. 

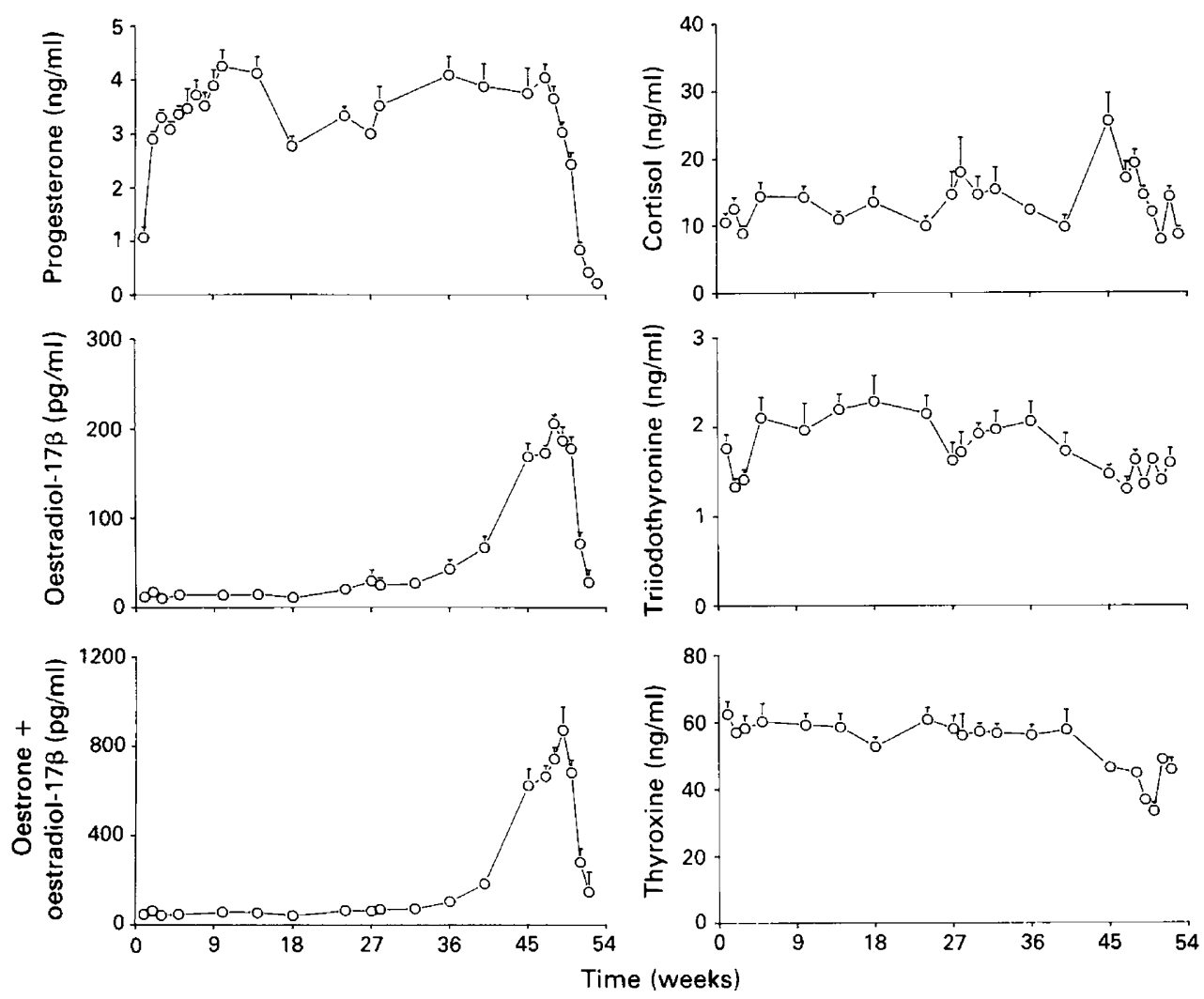

Fig. 2. Mean ( \pm s.e.m.) plasma progesterone, cortisol, triiodothyronine and thyroxine and serum oestradiol- $17 \beta$ and combined oestrone + oestradiol- $17 \beta$ concentrations between mating and parturition in the llama $(\mathrm{N}=14)$.

Combined oestrone + oestradiol- $17 \beta$ concentrations remained relatively constant $(67 \cdot 0 \pm$ $5.0 \mathrm{pg} / \mathrm{ml}$ ) from mating until 36 weeks of pregnancy, then increased, and reached peak concentrations of $827.0 \pm 58.0 \mathrm{pg} / \mathrm{ml}$ at 49 weeks after mating. The combined oestrone + oestradiol-17 $\beta$ concentrations remained elevated during the 2 weeks pre partum until $24 \mathrm{~h}$ pre partum when they declined significantly $(P<0.05)$ to $171.0 \pm 87.0 \mathrm{pg} / \mathrm{ml}$ at parturition. The concentrations of oestrone + oestradiol- $17 \beta$ after parturition remained stable at $76.0 \pm 11.0 \mathrm{pg} / \mathrm{ml}$ during the first week post partum $(P>0.05)$.

Serum oestradiol- $17 \beta$ concentrations were also reasonably constant $(18 \cdot 0 \pm 21 \cdot 0 \mathrm{pg} / \mathrm{ml})$ from mating until about Week 37 of pregnancy, then increased to a maximum concentration of $196.0 \pm 10 \cdot 0 \mathrm{pg} / \mathrm{ml}$ at Week 48 after mating. No significant changes $(P>0.05)$ were observed during the 2 weeks pre partum until the day of parturition when oestradiol-17 $\beta$ concentrations declined rapidly to $42 \cdot 0 \pm 26.0 \mathrm{pg} / \mathrm{ml}$ on the day of parturition. During the next 7 days, concentrations remained low $(25.4 \pm 4.9 \mathrm{pg} / \mathrm{ml})$ and did not vary significantly $(P>0.05)$.

Plasma triiodothyronine concentrations averaged $1.9 \pm 0.9 \mathrm{ng} / \mathrm{ml}(0.5-4.4 \mathrm{ng} / \mathrm{ml})$ between mating and parturition. No significant changes $(P>0.05)$ were observed during pregnancy or the periparturient period. Thyroxine concentrations did not vary substantially until Week 41 of pregnancy $(58.1 \pm 0.9 \mathrm{ng} / \mathrm{ml})(21.3-91.5)$, then declined $(P<0.02)$ to a minimum concentration of $24.0 \pm 5.0 \mathrm{ng} / \mathrm{ml} 1$ day before parturition. Starting 1 day pre partum, thyroxine concentrations then increased again to $53.0 \pm 4.0 \mathrm{ng} / \mathrm{ml}$ by I day post partum. The thyroxine concentration did not vary significantly $(P>0.05)$ during the first week post partum. 

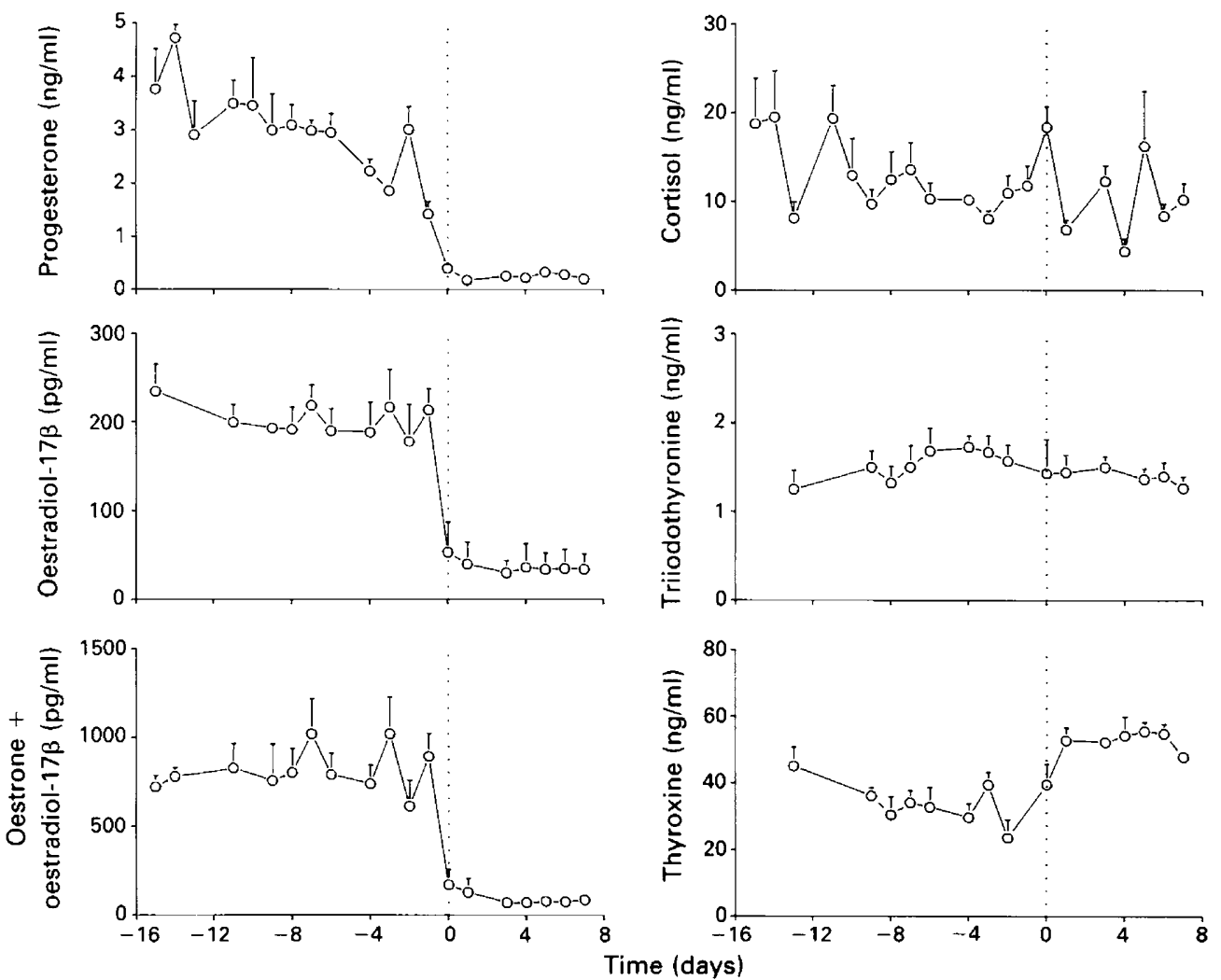

Fig. 3. Mean ( \pm s.e.m.) plasma progesterone, cortisol, triiodothyronine and thyroxine and serum oestradiol-17 $\beta$ and combined oestrone + oestradiol-17 $\beta$ concentrations from 15 days before to 7 days after parturition in the llama $(\mathrm{N}=14)$. Day 0 (broken vertical line) was the day of parturition.

\section{Discussion}

Plasma progesterone concentrations in the llama were significantly elevated by 5 days after mating and remained high during pregnancy. The mean progesterone concentrations $(3 \cdot 0-4.5 \mathrm{ng} / \mathrm{ml})$ were similar to those reported for many other species during the same stage of pregnancy. Progesterone concentrations during the first month after mating have been reported to vary between 6 and $12 \mathrm{ng} / \mathrm{ml}$ in the pig (Killian et al., 1973; Ash \& Heap, 1975), 2 and $10 \mathrm{ng} / \mathrm{ml}$ in the cow (Pope et al., 1969; Evans \& Wagner, 1976), 2 and $3 \mathrm{ng} / \mathrm{ml}$ in the ewe (Basset et al., 1969), and 3 and $7 \mathrm{ng} / \mathrm{ml}$ (Elias et al., 1984b; Agarwal et al., 1987) in the dromedary camel.

Progesterone concentrations in the llama declined slightly between 18 and 27 weeks of pregnancy. A similar transitory decline in progesterone concentrations has been observed in the dromedary camel at 21 weeks of pregnancy (Elias et al., 1984b). The physiological significance of this observation is unknown, as the role of the placenta in steroidogenesis in the llama has not been elucidated. The regulatory mechanism(s) associated with the gradual decline in progesterone concentrations during the 2 weeks before parturition is also unknown. A similar pre-partum decline has been observed in the dromedary camel, although the time course of the decline is different. In the camel, progesterone production has been reported to decline starting at 5 months of pregnancy (Elias et al., 1984b). The final decline in plasma progesterone concentrations began $24-48 \mathrm{~h}$ pre 
partum, temporal changes similar to those reported in some other species (Bassett et al., 1969; Pope et al., 1969; Stabenfeldt et al., 1972; Chamley et al., 1973; Smith et al., 1973; Challis et al., 1974; Robertson \& King, 1974; Ash \& Heap, 1975; Baldwin \& Stabenfeldt, 1975; Fairclough et al., 1975b; Hunter et al., 1977).

Alpacas have substantial serum concentrations of $20 \alpha$-dihydroprogesterone in addition to progesterone (Fernandez-Baca et al., 1970). Due to the low cross-reactivity of the primary antiserum for $20 \alpha$-dihydroprogesterone $(2.0 \%)$, changes in serum concentrations of $20 \alpha$-dihydroprogesterone during pregnancy could not be evaluated. The physiological importance, if any, of this progesterone metabolite in the llama is unknown.

Substantial changes in cortisol concentration during pregnancy and parturition have been previously reported for many domestic species including the cow, ewe, pig and goat (Adams \& Wagner, 1970; Chamley et al., 1973; Smith et al., 1973; Thompson \& Wagner, 1974; Baldwin \& Stabenfeldt, 1975; Hunter et al., 1977). Scott et al. (1984), working with the rhesus macaque, reported similar stable cortisol concentration in the maternal circulatory system before and during parturition. The llama may be similar to the rhesus monkey exhibiting only minor changes in cortisol concentrations during the periparturient period. This is in contrast to work in the ewe, sow and cow in which substantial increases in maternal corticosteroid concentrations occurred before parturition (Adams \& Wagner, 1970; Chamley et al., 1973; Killian et al., 1973; Molokwu \& Wagner, 1973; Smith et al., 1973). One possible explanation for the absence of a dramatic periparturient increase in glucocorticoid concentrations in the llama may have been the relatively low sampling frequency during this period ( 3 samples per week). A periparturient increase in cortisol could easily have been missed. There is no obvious explanation for the decline in mean glucocorticoid concentrations observed during the 2 weeks immediately pre partum.

Changes in serum oestrone and oestradiol-17 $\beta$ concentrations reported in this study are similar to those reported for the pig (Guthrie et al., 1972; Molokwu \& Wagner, 1973), cow (Henricks et al., 1972), and ewe (Chamley et al., 1973). Oestrogen concentrations have previously been reported to increase during pregnancy in other camelids. Agarwal et al. (1987), working with dromedary camels, reported that oestradiol-17 $\beta$ concentrations increased progressively during pregnancy from a basal concentration of $20 \mathrm{pg} / \mathrm{ml}$ at $2-3$ months of pregnancy to about $450 \mathrm{pg} / \mathrm{ml}$ during the final stage of gestation. Elias et al. (1984a) reported that the oestradiol-17 $\beta$ concentrations in the dromedary camel had increased dramatically from $338 \mathrm{pg} / \mathrm{ml}$ at 10 months of pregnancy to a peak of $606 \mathrm{pg} / \mathrm{ml}$ at Week 48 of pregnancy. In this study, a similar pattern for oestradiol-17 $\beta$ concentrations occurred although the basal concentrations were lower, $10-46 \mathrm{pg} / \mathrm{ml}$, during the majority of pregnancy before reaching a peak of $196 \pm 10 \mathrm{pg} / \mathrm{ml}$ during the final third of pregnancy.

In camels, follicular development during early pregnancy has been reported by Elwishy et al. (1981) to occur in spite of the presence of the corpus luteum. High concentrations of oestrogen in allantoic fluid on the day of parturition have also been demonstrated, suggesting the placenta as a probable source of oestrogen (Elias et al., 1984a). The rising concentrations of oestrogen during pregnancy in the llama may, therefore, be from either a follicular or placental origin.

Plasma triiodothyronine concentrations in the llama were relatively unchanged during the periparturient period, while thyroxine concentration decreased before parturition, and then increased to preparturient levels in the immediate post-partum period. The triiodothyronine concentrations were similar to those previously reported for pregnant llamas (Smith et al., 1989), and thyroxine concentrations in this study $(58.1 \pm 0.9 \mathrm{ng} / \mathrm{ml})$ were in the lower end of the range previously reported for pregnant llamas (Smith et al., 1989). These concentrations are similar to those reported for the goat (Riis \& Madsen, 1985). In the dromedary camel, triiodothyronine and thyroxine concentrations increased throughout pregnancy (Heshmat et al., 1984), while thyroxine concentrations in the goat decreased 1-2 days before parturition (Riis \& Madsen, 1985) perhaps as a result of nutrient redistribution to the mammary gland in preparation for lactation (Riis \& Madsen, 1985). A similar explanation for the changes in thyroxine concentrations in the llama may be applicable. 
We thank Commander Bud Deacon for help in making animals available and $\mathrm{Mr}$ Dan Schoenthal for assisting in sample collection.

This work was supported in part by grants from the International Llama Association, the Willamette Valley Llama Association and the Central Oregon Llama Association.

\section{References}

Adams, W.M. \& Wagner, W.C. (1970) The role of corticoids in parturition. Biol. Reprod. 3, 223-228.

Agarwal, S.P., Khanna, N.D., Agarwal, V.K. \& Dwaraknath, P.K. (1987) Circulating levels of estrogen and progesterone in female camel (Camelus dromedarius) during pregnancy. Theriogenology 28, 849-858.

Ash, R.W. \& Heap, R.B. (1975) Oestrogen, progesterone and corticosteroid concentrations in peripheral plasma of sows during pregnancy, parturition, lactation and after weaning. J. Endocr. 64, 141-154.

Baldwin, D.M. \& Stabenfeldt, G.H. (1975) Endocrine changes in the pig during late pregnancy, parturition and lactation. Biol. Reprod. 12, 508-515.

Bassett, J.M., Oxborrow T.J., Smith, I.D. \& Thorburn, G.D. (1969) The concentration of progesterone in the peripheral plasma of the pregnant ewe. J. Endocr. 45, 449-457.

Bazer, F.W. \& First, N.L. (1983) Pregnancy and parturition. J. Anim. Sci. 57 (Suppl. 2), 425-460.

Bedford, C.A., Challis, G.R.G., Harrison, F.A. \& Heap, R.B. (1972) The role of oestrogens and progesterone in the onset of parturition in various species. $J$. Reprod. Fert. 16, 1-23.

Challis, J.R.G., Davies, I.J. \& Ryan, K.J. (1974) The concentrations of progesterone, estrone and estradiol$17 \beta$ in the myometrium of the pregnant rabbit and their relationship to the peripheral plasma steroid concentrations. Endocrinology 95, 160-164.

Chamley, W.A., Buckmaster, J.M., Cerini, M.E., Cumming, I.A., Goding, J.R., Obst, J.M., Williams, A. \& Winfield, C. (1973) Changes in the levels of progesterone, corticosteroids, estrone, estradiol-17 $\beta$, luteinizing hormone, and prolactin in the peripheral plasma of the ewe during late pregnancy and at parturition. Biol. Reprod. 9, 30-35.

Csapo, A.I., Knobil, E., van der Molen, H.J. \& Wiest, W.G. (1971) Peripheral plasma progesterone levels during human pregnancy and labor. Am. J. Obstet. Gynec. $110,630-632$.

Elias, E., Bedrak, E. \& Yagil, R. (1984a) Estradiol concentration in the serum of the one-humped camel (Camelus dromedarius) during the various reproductive stages. Gen. comp. Endocrinol. 56, 258-264.

Elias, E., Bedrak, E. \& Yagil, R. (1984b) Peripheral blood levels of progesterone in female camels during various reproductive stages. Gen. comp. Endocrinol. 53, 235-240.

Elwishy, A.B., Hemeida, N.A., Omar, M.A., Mobarak, A.M. \& Elseyeb, M.A.I. (1981) Functional changes in the pregnant camel with special reference to fetal growth. Br. vet. J. 137, 527-537.

Evans, L.E. \& Wagner, W.C. (1976) Bovine plasma estrogens, progesterone and glucocorticoids during dexamethasone induced parturition. Acta endocr., Copenh. 81, 385-397.

Fairclough, R.J., Hunter, J.T., Welch, R.A.S. \& Payne, E. (1975a) Plasma corticosteroid concentrations in the bovine foetus near term. J. Endocr. 65, 139-140.

Fairclough, R.J., Hunter, J.T. \& Welch, R.A.S. (1975b) Peripheral plasma progesterone and utero-ovarian prostaglandin $\mathrm{F}$ concentrations in the cow around parturition. Prostaglandins 9, 90I-914.

Fernandez-Baca, S., Hansel, W. \& Novoa, C. (1970) Corpus luteum function in the alpaca. Biol. Reprod. 3, 252-261.

First, N.L. \& Bosc, M.J. (1979) Proposed mechanisms controlling parturition and the induction of parturition in swine. J. Anim. Sci. 48, 1407-1421.

Guthrie, H.D., Henricks, D.M. \& Handlin, D.L. (1972) Plasma estrogen, progesterone and luteinizing hormone prior to estrus and during early pregnancy in pigs. Endocrinology 91, 675-679.

Henricks, D.M., Dickey, J.F., Hill, J.R. \& Johnston, W.E. (1972) Plasma estrogen and progesterone levels after mating, and during late pregnancy and postpartum in cows. Endocrinology 50, 1336-1342.

Heshmat, H.A., Tha, A., Ismail, A.A. \& Sami, M.B.A. (1984) Levels of thyroid hormones in the plasma of pregnant camels (Camelus dromedarius). Indian $J$. Anim. Sci. 54, 663-665.

Hoffmann, B., Wagner, W.C., Ratterberger, E. \& Schmidt, J. (1977) Endocrine relationships during late gestation and parturition in the cow. Ciba Fdn Symp. 47, pp. 107-122.

Hunter, J.T., Fairclough, R.J., Peterson, A.J. \& Welch, R.A.S. (1977) Foetal and maternal hormonal changes preceding normal bovine parturition. Acta endocr., Copenh. 84, 653-662.

Killian, D.B., Garverick, H.A. \& Day, B.N. (1973) Peripheral plasma progesterone and corticoid levels at parturition in the sow. J. Anim. Sci. 37, 1371-1375.

Llauro, J. L., Runnebaum, B. \& Zander, J. (1968) Progesterone in human peripheral blood before, during and after labor. Am. J. Obstet. Gynecol. 101, $867-873$.

Molokwu, E.C.I. \& Wagner, W.C. (1973) Endocrine physiology of the puerperal sow. J. Anim. Sci. 36, 1158-1163.

Peterson, A.J., Hunter, J.T., Welch, R.A.S. \& Fairclough, R.J. (1975) Oestrogens in bovine fetal and maternal plasma near term. J. Reprod. Fert. 43, 179-181.

Pope, G.S., Gupta, S.K. \& Munro, I.B. (1969) Progesterone levels in the systemic plasma of pregnant, cycling and ovariectomized cows. J. Reprod. Fert. 20, 369-381.

Riis, P.M. \& Madsen, A. (1985) Thyroxine concentrations and secretion rates in relation to pregnancy, lactation and energy balance in goats. $J$. Endocr. 107, 421-427. 
Robertson, H.A. \& King, G.J. (1974) Plasma concentrations of progesterone, oestrone, oestradiol-17 $\beta$ and of oestrone sulphate in the pig at implantation, during pregnancy and at parturition. J. Reprod. Fert. 40, 133-141.

Scott, W.W., Stanczyk, F.Z. \& Novy, M.J. (1984) Daily hormonal changes in the maternal, fetal, and amniotic fluid compartments before parturition in a primate species. J. clin. Endocr. Metab. 58, 629-639.

Smith, B.B., Pearson, E.G. \& Leon, J. (1989) Thyroid function testing in the llama (Lama glama): an evaluation of normal triiodothyronine and thyroxine concentrations. Am. J. vet. Res. 50, 1215-1219.

Smith, V.G., Edgerton, L.A., Hafs, H.D. \& Convey, E.M. (1973) Bovine serum estrogens, progestins and glucocorticoids during late pregnancy, parturition and early lactation. J. Anim. Sci. 36, 391-396.

Soliman, F.A., Nasr, H. \& Zaki, K. (1963) Levels of thyroid and thyrotrophic hormones in the blood of Friesian cows at various reproductive stages. $J$. Reprod. Fert. 6, 335-340.

Stabenfeldt, G.H., Osburn, B.I. \& Ewing, L.L. (1970) Peripheral plasma progesterone levels in the cow during pregnancy and parturition. Am. J. Physiol. 218, $571-575$.
Stabenfeldt, G.H., Drost, M. \& Franti, C.E. (1972) Peripheral plasma progesterone levels in the ewe during pregnancy and parturition. Endocrinology 90, 144-150.

Thompson, F.N. (1973) Feto-placental steroids and parturition in the ewe. Ph.D. thesis, lowa State University, Ames.

Thompson, F.N. \& Wagner, W.C. (1974) Fetal-maternal corticosteroid relationships in sheep during late pregnancy. J. Reprod. Fert. 41, 49-56.

Thorburn, G.D., Nicol, D.H., Bassett, J.M., Shutt, D.A. \& Cox, R.I. (1972) Parturition in the goat and sheep: changes in corticosteroids, progesterone, oestrogens and prostaglandin F. J. Reprod. Fert. 16, 61-84.

Wagner, W.C. \& Oxenreider, S.L. (1971) Endocrine physiology following parturition. J. Anim. Sci. 32, 1-16.

Wagner, W.C., Thompson, F.N., Evans, L.E. \& Molokwu, E.C.I. (1974) Hormonal mechanisms controlling parturition. J. Anim. Sci. 38, 39-57.

Received 26 May 1989 